\title{
SISTEM VERIFIKASI SERTIFIKAT SEMINAR DENGAN QR CODE SEBAGAI IDENTITAS UNIK TERENKRIPSI
}

\author{
Morteza Muthahhari ${ }_{-}^{1}$, Yus Sholva ${ }^{2}$, Hengky Anra ${ }^{3}$ \\ 1,2,3 Jurusan Informatika Fakultas Teknik Untan, Pontianak \\ ${ }^{1,2}$ Kelompok Keahlian Sistem Informasi dan Data Spasial \\ ${ }^{3}$ Kelompok Keahlian Rekayasa Perangkat Lunak \\ dan Komputasi Bergerak
}

Email korespondensi :

morteza.muthahhari@teknik.untan.ac.id

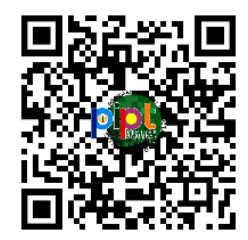

$10.26418 /$ pipt.2021.34

\begin{abstract}
Abstrak
Sertifikat seminar yang diperoleh seorang dosen umumnya digunakan sebagai bukti penilaian BKD (Beban Kerja Dosen) atau PAK (Penilaian Angka Kredit). Bukti sertifikat tersebut dinilai oleh asesor dengan melihat fisik sertifikat dan/atau file hasil pemindaian sertifikat. Masalah akan muncul jika asesor meragukan bukti sertifikat yang dinilainya, dan terlebih saat ini bukti sertifikat hanya berupa file PDF atau JPG yang mudah diubah (edit). Pertanyaannya adalah cara asesor memastikan bahwa benar telah diselenggarakan seminar dan metode memastikan nama yang tertera pada sertifikat adalah benar mengikuti kegiatan tersebut. Untuk itu, diperlukan suatu sistem yang bisa memberikan layanan verifikasi sertifikat. Dalam penelitian ini diusulkan pemberian identitas unik pada sertifikat berupa QR Code yang bereferensi ke alamat website (URL link) untuk proses verifikasi. Tiap sertifikat memiliki QR Code berbeda dan nama penerima sertifikat akan ditampilkan oleh sistem. Suatu string identitas atau signature khusus ditambahkan untuk membuat URL link menjadi unik. Hal ini dapat memastikan bahwa URL link tidak dimodifikasi sejak URL link tersebut dibuat. Penambahan identitas atau signature khusus ini menambah unsur keamanan yakni untuk mencegah manipulasi URL (URL manipulation). Oleh karena itu fungsi validasi diterapkan pada sistem untuk memastikan bahwa identitas atau signature pada URL link yang diterima dari QR Code valid. Setelah identitas URL link dipastikan valid oleh sistem, asesor sebagai verifikator akan diarahkan (redirect) ke verification page yang menampilkan informasi kegiatan seminar, nama penyelenggara, waktu pelaksanaan, dan nama penerima sertifikat. Dari data peserta dan informasi kegiatan seminar tersebut, asesor dapat melakukan verifikasi dan memastikan bahwa sertifikat yang dinilainya valid atau tidak.
\end{abstract}

Kata kunci: sertifikat, seminar, verifikasi, asesor, QR code.

\section{PENDAHULUAN}

Dalam konteks kegiatan seperti seminar atau workshop, sertifikat dikeluarkan oleh suatu instansi atau panitia penyelenggara yang menerangkan bahwa nama orang yang disebut dalam sertifikat telah berpartisipasi pada kegiatan seminar atau workshop yang diselenggarakannya baik sebagai peserta maupun sebagai narasumber. Di lingkungan perguruan tinggi, sertifikat-sertifikat kegiatan baik itu seminar, workshop, lokakarya, pelatihan, dan sebagainya juga banyak dikeluarkan oleh penyelenggara kegiatan, baik tingkat universitas maupun fakultas. Perguruan tinggi sebagai lembaga ilmiah tentu saja sudah terbiasa menyelenggarakan kegiatan-kegiatan keilmiahan seperti itu. Bagi para dosen mengikuti kegiatan keilmiahan tersebut merupakan salah satu kewajiban dalam unsur penelitian baik sebagai keynote speaker, pembicara, partisipan dengan makalah, atau hanya sebagai partisipan tanpa makalah. Bukti otentik keterlibatan dosen dalam kegiatan tersebut salah satunya diwujudkan dalam bentuk sertifikat yang berisi nama partisipan, peran, tanggal kegiatan, dan dibubuhi tanda tangan dan stempel pihak terkait.

Sertifikat yang diperoleh seorang dosen digunakan untuk penilaian BKD (Beban Kerja Dosen) maupun PAK (Penilaian Angka Kredit). Penilaian atas bukti berupa sertifikat dilakukan oleh sejawat dosen yang lainnya 
yang ditugasi sebagai asesor. Asesorlah yang melakukan penilaian dengan melihat bukti fisik sertifikat dan/atau hasil pemindaian (scan) sertifikat. Seorang asesor akan memeriksa apakah bukti sertifikat yang diberikan adalah benar atas nama yang bersangkutan yang tertera di dalam sertifikat. Kemudian asesor menentukan lingkup kegiatan apakah skala internasional, regional, nasional, daerah, atau institusi. Unsur penilaian lainnya adalah peran penerima sertifikat, apakah keynote speaker, pembicara tamu, atau partisipan. Proses penilaian ini mesti dilakukan seorang asesor dengan cermat dan penuh tanggung jawab.

Dalam proses penilaian sertifikat, mungkin seorang asesor akan menemui kesulitan mana kala akan memeriksa keabsahan sertifikat, dalam arti untuk meyakinkan bahwa memang benar telah diselenggarakan kegiatan sebagai tertera pada sertifikat dan memang benar nama yang tertera pada sertifikat mengikuti kegiatan dimaksud. Masalah akan muncul jika asesor meragukan bukti sertifikat yang dinilainya terlebih saat ini bukti sertifikat hanya berupa file PDF atau JPG. Verifikasi sertifikat yang umum dilakukan adalah dengan melihat nama yang tertera di dalam sertifikat. Jika namanya sesuai maka sertifikat tersebut dianggap sah. Verifikasi sertifikat hanya berdasarkan kepercayaan saja, yakni cukup ada atau tidaknya sertifikat. Untuk memverifikasi sertifikat sampai level detil merupakan pekerjaan yang melelahkan bagi asesor, apalagi jumlah sertifikat yang dinilai sangat banyak. Asesor bisa saja melakukan pencarian konten internet (website) namun belum tentu semua panitia penyelenggara kegiatan memiliki website. Misalkan sudah ada website yang biasanya untuk keperluan publikasi kegiatan, belum tentu tersedia daftar nama perserta kegiatan apalagi contoh sertifikat yang diterbitkan oleh penyelenggara. Hal-hal ini sangat merepotkan seorang asesor sehingga asesor melakukan penilai dengan referensi yang minimal, yaitu jika sertifikatnya tersedia (walaupun file scan) dan nama yang tertera sudah sesuai maka bisa dilakukan penilaian.
Berdasarkan hal tersebut di atas, menunjukkan perlunya dibangun suatu sistem verifikasi yang dapat menunjukkan keaslian sertifikat (baik fisik atau file hasil scan). Verifikasi ini salah satunya dapat dilakukan dengan membuat aplikasi verifikasi sertifikat berbasis QR Code. Sertifikat yang dapat diverifikasi adalah sertifikat yang sudah dibubuhi QR Code yang dibangkitkan dari sistem. QR Code menyimpan kode tertentu misalnya berupa teks link URL (Uniform Resource Locator) yang akan mengarah ke website penyelenggara kegiatan. Dengan adanya QR Code tersebut dapat membantu pihak-pihak yang berkepentingan dalam melakukan verifikasi sertifikat, misalnya asesor $B K D$ dan PAK.

Quick Response Code atau disingkat QR Code adalah image dua dimensi yang merepresentasikan suatu data, terutama data berbentuk teks. QR Code memiliki kemampuan menyimpan data yang lebih jauh besar daripada Barcode. Seiring dengan perkembangan teknologi yang begitu pesatnya, penggunaan Barcode kini mulai digantikan dengan QR Code (Ardhianto \& Wahyudi, 2015). QR Code mampu mengkodekan data baik dalam arah horizontal dan vertikal, sehingga mampu menyandikan beberapa kali lebih banyak data daripada Barcode (Rani \& Euphrasia, 2016).

QR Code banyak digunakan untuk keperluan komersil, biasanya berisi link URL ke alamat tertentu atau sekedar teks berisi iklan, promosi, dan lain-lain (Nugraha \& Munir, 2011). QR Code diperkenalkan pada tahun 1994 oleh Denso-Wave, anak perusahaan Jepang dari Toyota. Awalnya, kode-kode ini dianggap sebagai cara cepat untuk melacak suku cadang kendaraan (Sonawane et al., 2014).

Penggunaan QR Code sudah banyak diaplikasikan di berbagai bidang, misalnya QR Code pada sistem kasir (Dirayati \& Sukemi, 2019), untuk tujuan pemasaran, pemberian informasi, vCard, atau hyperlink (Handoko \& Hardiyanti, 2016). Terdapat juga penelitian yang memanfaatkan gambar QR Code untuk pengecekan keaslian ijazah 
mahasiswa (Widiantoro, 2015), dan di Universitas Tanjungpura sendiri QR Code sudah digunakan dalam presensi online mahasiswa. Selain itu, penelitian mengenai sistem verifikasi sertifikat menggunakan QR Code untuk keamanan sertifikat pernah dilakukan di Perguruan Tinggi Raharja. Penelitian ini menerapkan QR Code guna memperlancar proses verifikasi secara online. Hasilnya adalah sertifikat yang sudah memiliki unsur keamanan berupa QR Code yang dibangkitkan (generate) secara otomatis. (Febriyanto dkk., 2019).

\section{METODOLOGI}

Pada penelitian ini menggunakan model pengembangan sistem dengan pendekatan prototipe. Konsep utama pengembangan sistem berbasis prototipe yakni adanya pembagian alur kerja secara keseluruhan menjadi beberapa tahapan iterasi (Hidayat dkk., 2015).

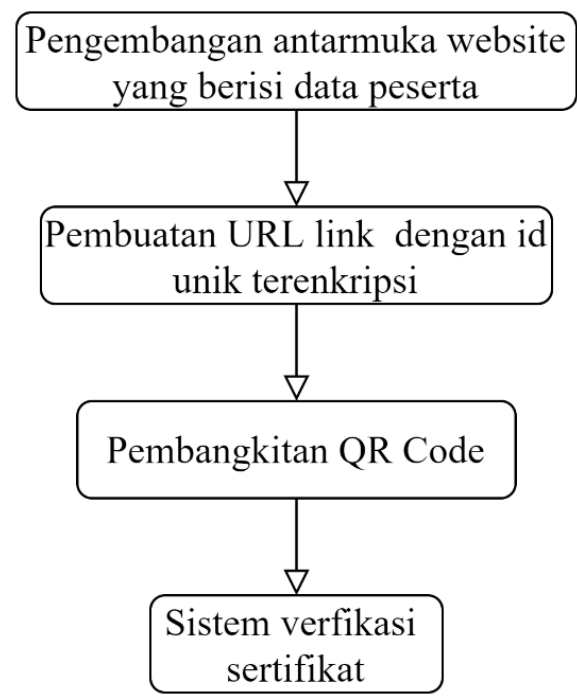

Sumber: (Penulis, 2021)

Gambar 1: Metode Penelitian

Tahapan-tahapan iterasi dalam penelitian ini adalah sebagai berikut: (1) tahapan iterasi pertama merupakan pengembangan antarmuka halaman website yang akan menampilkan informasi mengenai kegiatan seminar beserta data pesertanya; (2) Tahap iterasi kedua adalah pembuatan URL link dengan id unik terenkripsi menggunakan fungsi signedRoute pada controller laravel framework. URL dengan id terenkripsi dapat mencegah URL manipulation. (https://laravel.com/docs/8.x/urls\#signed-

urls); (3) Tahap iterasi ketiga adalah pembangkitan QR Code dari URL dengan id terenkripsi yang telah dibuat sebelumnya; dan (4) Tahapan terakhir adalah proses verifikasi sertifikat pada sistem dengan $Q R$ Code sesuai URL yang terkandung dalam QR Code.

Penelitian ini dilakukan pada laboratorium Informatika Jurusan Teknik Informatika Universitas Tanjungpura. Penelitian ini dibatasi hanya dalam ruang lingkup Universitas Tanjungpura Pontianak.

\section{HASIL DAN PEMBAHASAN}

Berdasarkan tahapan iterasi dalam pengembangan sistem, tahap iterasi pertama adalah mengembangkan antarmuka halaman website yang akan menampilkan informasi mengenai kegiatan seminar beserta pesertanya. Dari halaman website ini asesor dapat membandingkan sekaligus memverifikasi data peserta yang tercantum dalam sertifikat, apakah sesuai atau tidak. 


\begin{tabular}{|c|c|c|}
\hline \multicolumn{3}{|l|}{ Data peserta } \\
\hline Nama & & Fransiska Risa Denibetri \\
\hline Event & : & $\begin{array}{l}\text { Webinar Nasional } \\
\text { dengan Topik : Desa } \\
\text { Mandiri Peduli Gambut } \\
\text { dalam Kerangka } \\
\text { Indikator Sustainable } \\
\text { Development Goals } \\
\text { Berbasis Desa (SGDs } \\
\text { Desa) }\end{array}$ \\
\hline Oleh & : & $\begin{array}{l}\text { Himpunan Mahasiswa } \\
\text { Informatika (HMIF FT } \\
\text { UNTAN) } \\
\text { Jurusan/Prodi } \\
\text { Informatika } \\
\text { Fakultas Teknik } \\
\text { Universitas } \\
\text { Tanjungpura }\end{array}$ \\
\hline Sebagai & : & PESERTA \\
\hline $\begin{array}{l}\text { Terdaftar } \\
\text { Pada }\end{array}$ & : & $\begin{array}{l}\text { Sabtu, } 27 \text { Maret } 2021 \\
\text { pukul } 02.15 \text { Wib }\end{array}$ \\
\hline $\begin{array}{l}\text { Nomor } \\
\text { Sertifikat }\end{array}$ & : & $\begin{array}{l}\text { Nomor: } \\
\text { 748/P.10/UN22.10/2020 }\end{array}$ \\
\hline
\end{tabular}

Gambar 2: Data peserta pada halaman website

Tahapan yang kedua adalah pembuatan URL link dengan id unik terenkripsi menggunakan laravel framework. Id peserta akan ditambahkan string unik dengan fungsi signedRoute pada bagian controller.

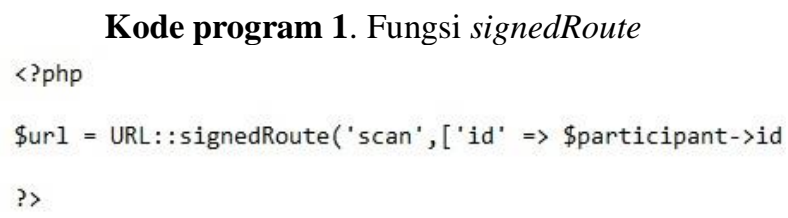

Hasil dari fungsi ini adalah penambahan suatu id atau signature unik pada URL seperti contoh pada gambar 3 di bawah ini.

/verifikasi $/ 10$ ? signature $=0$ af 8 df $3 f 795922$ bce $58 \mathrm{fd} 6 \mathrm{dd} 4 \mathrm{f} 1$ ede $4 \mathrm{fe} 40 \mathrm{fb} 8015$

Gambar 3: URL dengan identitas unik

Tahapan iterasi yang ketiga adalah pembangkitan QR Code. Hal ini dilakukan dengan laravel framework pada bagian controller. Kode program untuk pembangkitan QR Code dapat dilihat pada kode program 2 di bawah ini.
Kode program 2. QR Code Generator

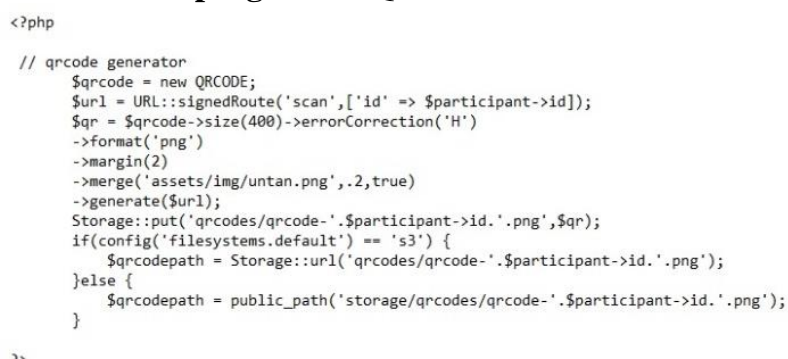

QR Code yang dihasilkan akan dibubuhi pada sertifikat kegiatan. Dari sertifikat tersebut, para asesor atau verifikator dapat melakukan scan terhadap QR Code yang terdapat pada sertifikat, dan akan diarahkan ke halaman website yang berisi data peserta serta informasi kegiatan yang diselenggarakan sesuai sertifikat.

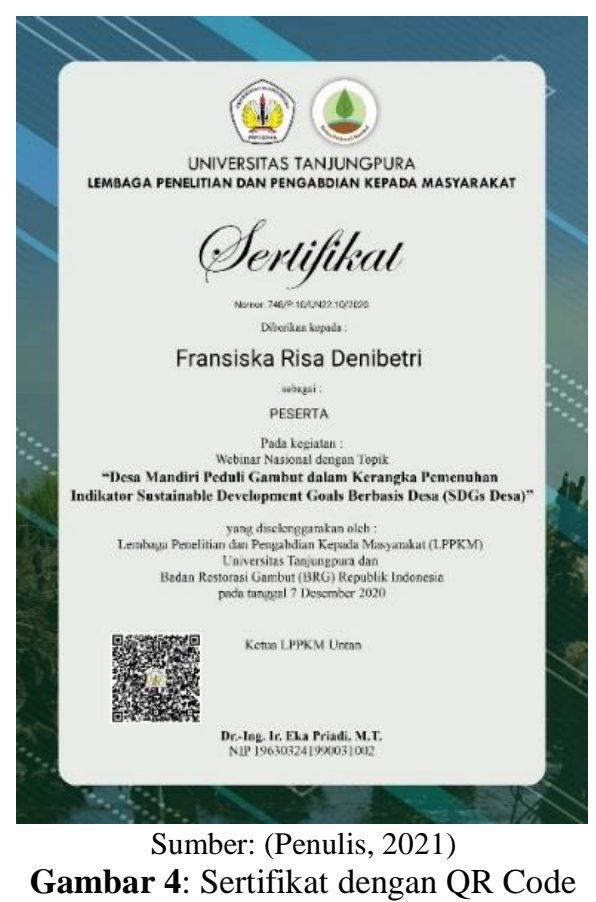

Tahapan terakhir adalah proses verifikasi sertifikat menggunakan QR Code. Dari URL yang terdapat dalam QR Code hasil scan, sistem akan melakukan validasi id atau signature sertifikat menggunakan routing pada laravel framework. Fungsi yang digunakan adalah route middleware.

Kode program 3. Fungsi Validasi id Sertifikat$$
<\text { ?php }
$$$$
\text { Route: :get('/verifikasi/\{id\}', [Dashboardcontroller: :class, 'scan']) }
$$ 
Seandainya id atau signature URL tidak valid, maka akan ditampilkan suatu halaman yang berisi pesan Invalid Signature seperti pada gambar 5 berikut ini.

\section{INVALID SIGNATURE.}

Sumber: (Penulis, 2021)

Gambar 5: Pesan Invalid Signature

Setelah signature dalam URL berhasil divalidasi, maka asesor akan dibawa ke halaman website yang berisi data peserta dan informasi kegiatan sesuai dengan yang tertera pada sertifikat. Di sini asesor bisa membandingkan dan memverifikasi keabsahan sertifikat sesuai dengan informasi yang disajikan dalam halaman website. Proses verifikasi sertifikat oleh asesor sebagai verifikator dapat dilihat pada gambar 6 berikut.

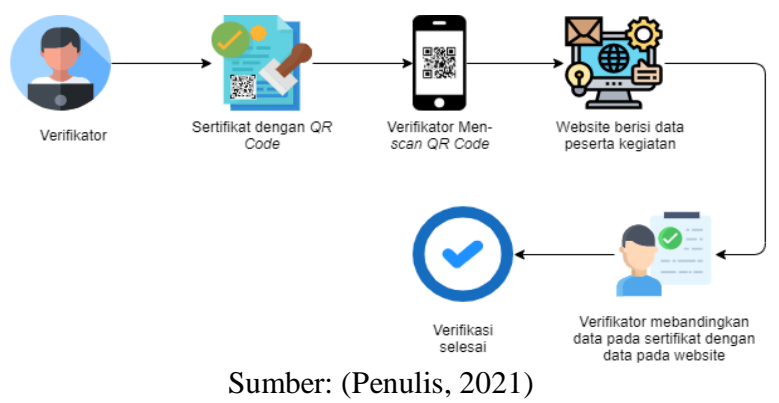

Gambar 6: Proses verifikasi sertifikat

Gambaran umum proses verifikasi sertifikat oleh asesor sebagai verifikator adalah sebagai berikut:

1. Asesor sebagai verifikator merupakan orang yang berwenang untuk melakukan verifikasi terhadap sertifikat. Verifikator mendapatkan sertifikat yang sudah dibubuhi QR Code dalam bentuk fisik maupun file.

2. Sertifikat yang telah didapatkan kemudian di-scan oleh verifikator menggunakan aplikasi QR Code scanner sesuai sistem operasi yang digunakan verfikator.
3. Dari proses scan sertifikat kemudian akan dialihkan ke website yang berisi data peserta sesuai link yang tersimpan di dalam QR Code.

4. Asesor yang bertindak sebagai verifikator akan membandingkan data pada sertifikat dengan data pada website untuk memverifikasi keaslian sertifikat. Dengan ini proses verifikasi selesai.

\section{KESIMPULAN}

Kesimpulan yang didapat dari penelitian ini adalah:

1. Penggunaan QR Code dapat diaplikasikan di berbagai bidang, salah satunya diterapkan untuk keperluan verifikasi sertifikat seminar.

2. Sistem verifikasi sertifikat dengan $Q R$ Code yang diusulkan berfungsi membantu asesor sebagai verifikator untuk mengecek keabsahan dari sertifikat yang ada sehingga mendukung kemudahan dalam penilaian untuk BKD ataupun PAK.

3. Id unik pada URL dalam QR Code memberikan unsur keamanan yakni dapat mencegah URL manipulation.

\section{UCAPAN TERIMA KASIH}

Penulis mengucapkan terima kasih kepada segenap pihak yang terlibat dalam penelitian ini, serta tidak lupa ucapan terima kasih kepada Jurusan Informatika, Fakultas Teknik, Universitas Tanjungpura yang telah memberikan kesempatan dan dukungan kepada penulis dalam penelitian ini.

\section{DAFTAR PUSTAKA}

Ardhianto, E., Handoko, W.T., \& Wahyudi, E.N. (2015). Pengembangan Metode Otentikasi Keaslian Ijasah dengan Memanfaatkan Gambar QR Code. Dinamik-Jurnal Teknologi Informasi, 20(2), 106-114

Dirayati, F., \& Sukemi. (2019). Optimasi QR-Code pada Sistem Kasir di Industri Retail. Prosiding Annual 
Research Seminar 2019, 5(1), 207212

Febriyanto, E., Rahardja, U., Faturahman, A., \& Lutfiani, N. (2019). Sistem Verifikasi Sertifikat Menggunakan Qrcode Pada Central Event Information. Techno. Com, 18(1), 5063

Handoko, L., \& Hardiyanti, F. (2016). Pemanfaatan Teknologi Quick Response Code (QR Code) Untuk Verifikasi Data Pada Tahap Pembuktian Dokumen di Unit Layanan Pengadaan (ULP) Politeknik Perkapalan Negeri Surabaya. Prosiding Seminar Nasional Maritim, Sains, dan Teknologi Terapan 2016, 01, 173-178

Hidayat, E.Y., Firdausillah, F., \& Hastuti, K. (2015). Sistem Legalisir Scan Ijazah Online Berbasis QR Code dan Watermarking. Techno. Com, 14(1), 13-24.
Nugraha, M.P., \& Munir, R. (2011). Pengembangan Aplikasi QR Code Generator dan QR Code Reader dari Data Berbentuk Image. Prosiding Konferensi Nasional Informatika KNIF 2011, 148-155

Rani, M.M.S., \& Euphrasia, K.R. (2016). Data security through qr code encryption and steganography. Advanced Computing: An International Journal (ACIJ), 7(1/2), $1-7$

Sonawane, D., Upadhye, M., Bhogade, P., \& Bajpai, S. (2014). QR based Advanced authentication for all hardware platforms. International Journal of Scientific and Research Publications, 4(1), 1-4

Widiantoro, A.D. (2015). Implementasi Qrcode Pada Berkas Kelulusan Mahasiswa Berbasis Pdf Web. Prosiding Seminar Nasional Ilmu Komputer (SNIK 2015), 15-20 